\title{
IDENTIFIKASI JENIS BAMBU (Poaceae) DI HUTAN TEMBAWANG DERET JAT, DESA PERUAN DALAM KECAMATAN TAYAN HULU KABUPATEN SANGGAU
}

(Dentification of Types of Bamboo (Poaceae) in Jat Towards Forest, Village of Tayan Hulu District, Sanggau Regency)

\author{
Urbanus Alataris, Eddy Thamrin, Ratna Herawatiningsih \\ Fakultas Kehutanan Universitas Tanjungpura Pontianak, Jl. Daya Nasional Pontianak 78124 \\ Email: urbanusalataris24@gmail.com
}

\begin{abstract}
Bamboo belongs to the Gramineae family (grasses) also called Giant Grass. Bamboos live in clumps, consisting of a number of stems (reeds) that grow gradually, starting from bamboo shoots, young and adult stems at the age of 4-6 years. The stem of this plant is cylindrical, sectioned, segmented, occasionally having massive hollow, hard-walled, in each section there are buds or branches. This study aims to find out the type and to identify the type of bamboo that is in the Tembawang Deret Jat Forest of Peruan Dalam Village in the District of Tayan Hulu, Sanggau Regency. This research will be carried out with a survey method using sampling techniques in a systematic sampling method in the form of making paths. The path used is not determined by the number of lines with a width of 20 meters and the length of the path is not determined and the distance between the lines is 50 meters. In the area of Tembawang Deret Jat Forest of Peruan Dalam Village in Tayan Hulu Subdistrict, 7 types of bamboo were found, namely Gigantochloa robusta, Gigantochloa balui, Schizostachyum zollingeri, Schizostachyum sp, Dendrocalamus asper, Schizostachyum brachycladum, Schizostachyum silicatum, and 3 bamboo genera Dendrocalamus, Gigantochloa, Schizostachyum, Schizostachyum, Schizostachyum and one Poace family.
\end{abstract}

Keywords : Bamboo, Bamboo shoots, Clump, Reed, Tembawang forest.

\section{PENDAHULUAN}

Bambu tergolong keluarga Gramineae (rumput-rumputan) juga disebut Giant Grass (rumput raksasa). Tanaman ini di Indonesia ditemukan mulai dari dataran rendah sampai pegunungan. Pada umumnya ditemukan di tempat-tempat terbuka dan daerahnya bebas dari genangan air (Huzaemah et al, 2016). Widjaja (2001), mengatakan didunia terdapat sekitar 1200-1300 jenis sedangkan di wilayah Indonesia diperkirakan terdapat 157 jenis bambu. Jumlah jenis bambu tersebut kira-kira
$10 \%$ dari jenis bambu di dunia. Jenis bambu di dunia diperkirakan terdiri dari 1. $250-1.350$ jenis. Di antara jenis bambu yang terdapat di Indonesia, 50\% di antaranya merupakan bambu endemik yang telah dimanfaatkan oleh penduduk dan sangat berpotensi untuk dikembangkan (Widjaja dan Karsono, 2004).

Tanaman bambu yang sering kita kenal umumnya berbentuk rumpun. Padahal dapat pula bambu tumbuh sebagai batang soliter atau perdu. Tanaman bambu yang tumbuh subur di 
Indonesia merupakan tanaman bambu yang simpodial, yaitu batang-batangnya cenderung mengumpul didalam rumpun karena percabangan rhizomnya di dalam tanah cenderung mengumpul (Agus, 2006).

Banyaknya jenis bambu yang terdapat di Hutan Tembawang Deret Jat Desa Peruan Dalam Kecamatan Tayan Hulu Kabupaten Sanggau, masih belum diketahui jenisnya, maka perlu dilakukan identifikasi jenis-jenis bambu tersebut.

Penelitian ini bertujuan untuk mengetahui jenis dan untuk mengidentifikasi jenis bambu yang ada di Hutan Tembawang Deret Jat Desa Peruan Dalam Kecamatan Tayan Hulu Kabupaten Sanggau.

\section{BAHAN DAN METODE}

Penelitian ini dilaksanakan di Hutan Tembawang Deret Jat Desa Peruan Dalam Kecamatan Tayan Hulu Kabupaten Sanggau dengan waktu \pm 3 minggu efektif dilapangan. Penelitian ini dilaksanakan pada tanggal 17 Juli sampai dengan 7 Agustus 2018. Alat yang digunakan dalam pengambilan data yaitu peta lokasi skala 1:150.000, GPS untuk mengambil titik koordinat di lapangan, kompas untuk menentukan arah jalur penelitian, meteran dan tali rapia untuk mengukur dan membuat petak pengamatan, phi band untuk mengukur keliling rumpun bambu guna untuk mendapatkan diameter rumpun bambu, peralatan untuk herbarium ( alkohol, plastik packing, koran, gunting dan isolasi), parang untuk merintis jalur penelitian, kamera untuk dokumentasi dan alat tulis
Penelitian ini dilaksanakan dengan metode survei menggunakan teknik sampling dengan cara sistematis sampling berupa pembuatan jalur. Jalur yang digunakan tidak ditentukan jumlah jalurnya dengan lebar 20 meter serta panjang jalur tidak ditentukan dan jarak antara jalur 50 meter. Inventarisasi dilakukan pada jalur pengamatan, setiap bambu yang ditemukan dicatat jenis bambu, jumlah rumpun, jumlah batang tiap rumpun. Dari masing masing jenis bambu yang ditemukan dibuat dokumentasi yang lengkap tentang bagian bagian dari bambu agar mempermudah dalam melakukan identifikasi. Identifikasi jenis bambu dilakukan dengan berdasarkan ciri-ciri morfologi bambu dilapangan yang meliputi buluh, rumpun, jumlah buluh, jumlah rumpun, warna buluh, warna daun, bentuk pelepah, bentuk buku, bentuk daun, panjang buluh, panjang ruas, bentuk cabang, dari masing masing jenis bambu yang ditemukan dilokasi penelitian dengan menggunakan buku panduan dan bantuan pengenal jenis setempat (Widjaja,1977)

\section{HASIL DAN PEMBAHASAN}

\section{Jumlah Jenis dan Rumpun Bambu}

Dalam penelitian yang saya lakukan selama \pm 3 minggu dilapangan, banyaknya jalur penelitian yang saya lakukan sebanyak 24 jalur dengan jarak antara jalur 50 meter, lebar jaur 20 meter (10 meter kekanan dan 10 meter kekiri) dan panjangnya jalur 200-400 meter. Banyaknya jumlah rumpun bambu yang ditemukan pada setiap jalur pengamatan dapat dilihat pada tabel 10. Berdasarkan 
hasil identifikasi dilapangan yang dilaksanakan di kawasan Hutan Tembawang Deret Jat Desa Peruan Dalam Kecamatan Tayan Hulu Kabupaten Sanggau ditemukan 7 jenis bambu dari 3 genus yang berbeda, hal ini disesuaikan dengan yang diungkapkan
Widjaja (1995) bahwa jenis-jenis bambu yang terdapat di Indonesia merupakan jenis bambu yang tumbuh merumpun dan sebagian besar berasal dari genus Dendrocalamus, Gigantochloa dan Schizostachyum.

Tabel 1. Jenis-Jenis Bambu Yang Ditemukan Pada Kawasan Hutan Tembawang Deret Jat Desa Peruan Dalam Kecamatan Tayan Hulu Kabupaten Sanggau

\begin{tabular}{lllc}
\hline No & Nama Lokal & Genus & Nama Latin \\
\hline 1 & Ringko & Gigantochloa & Gigantochloa robusta \\
2 & Tarek & Gigantochloa & Gigantochloa balui \\
3 & Borok & Schizostachyum & Schizostachyum zollingeri \\
4 & Muntik & Schizostachyum & Schizostachyum sp \\
5 & Butuk & Dendrocalamus & Dendrocalamus asper \\
6 & Kuning & Schizostachyum & Schizostachyum brachycladum \\
7 & Temiang Pogok & Schizostachyum & Schizostachyum silicatum \\
\hline
\end{tabular}

Sumber : Analisis Data 2018

\section{Identifikasi Jenis Bambu (Poaceae)}

Adapun jenis bambu yang ditemukan pada Kawasan Hutan

Tembawang Deret Jat Desa Peruan

Dalam Kecamatan Tayan Hulu Kabupaten Sanggau adalah sebagai berikut:

\section{Bambu Ringko (Gigantochloa robusta)}

Batang bambu ringko memiliki rumpun yang rapat, bentuk batang tegak ujung melengkung dengan warna buluh muda hijau putih kekuningan, pada buluh tua hijau, bertotol putih dan hitam, permukaan batang kasar banyak bulu. Diameter batang antara 7-10 cm dan panjang antara ruas $30-60 \mathrm{~cm}$, tebal dinding ringko mencapai $5-10 \mathrm{~mm}$, tinggi batang mencapai 13-36 meter. Percabangan tumbuh jauh dari permukaan tanah dan tumbuh satu cabang yang paling besar. Daun bambu ringko memiliki permukaan yang agak kasar, balik daun terdapat bulu halus, pangkal daun berbentuk oval dengan ujung meruncing, kuping pelepah daun seperti bingkai tingginya $1 \mathrm{~mm}$, dengan bulu kejur 1-2 mm, ligula menggerigi setinggi $1 \mathrm{~mm}$, pertulangan daun sejajar seperti rumput, memiliki tulang daun utama yang menonjol, berwarna hijau, panjang daun $15-46 \mathrm{~cm}$, dan lebar daun 4-9 cm.

Pelepah buluh mudah luruh dan berwarna coklat, terdapat bulu berwarna hitam, yang hampir terdapat diseluruh bagian pelepah buluh, kuping pelepah buluh membulat dengan bulu kejur setinggi 1-2 $\mathrm{mm}$, ligula menggerigi tingginya $1 \mathrm{~mm}$, memiliki cuping dan ligula yang berkembang baik dan daun pelepah batang menyandak atau terkeluk balik dengan ujung meruncing, dengan panjang pelepah 15-29 cm, lebar $18 \mathrm{~cm}$ dan panjang daun pelepah 7-11 cm. Rebung berwarna hijau muda dan ujung 
rebung berwarna hijau keunguan, bentuk rebung mengkerucut dengan ukuran kecil sampai besar dengan dimeter 3-10 $\mathrm{cm}$ dan pelepah rebung berwarna coklat ditutupi bulu berwarna coklat sampai hitam dengan daun pelepah yang menyadak berwarna hijau keunguan. Akar berbentuk pakimorf (dicirikan oleh akar yang simpodial), akar terdapat dibawah tanah dan ada juga dibagian buku batang yang disebut akar udara, bagian pangkal akar lebih sempit dari pada ujungnya dan setiap ruas akar memiliki kuncup dan akar serabut yang bercabang banyak.

Habitat: bambu ringko tumbuh baik pada daerah tropis yang lembab dan kering, pada kawasan Hutan Tembawang Deret Jat Desa Peruan Dalam bambu ringko (Gigantochloa robusta) banyak tumbuh pada daerah yang cukup kering.

Kegunaan: Bagian buluh digunakan masyarakat sebagai kandang ternak dan bagian rebung digunakan masyarakat sebagai sayuran.

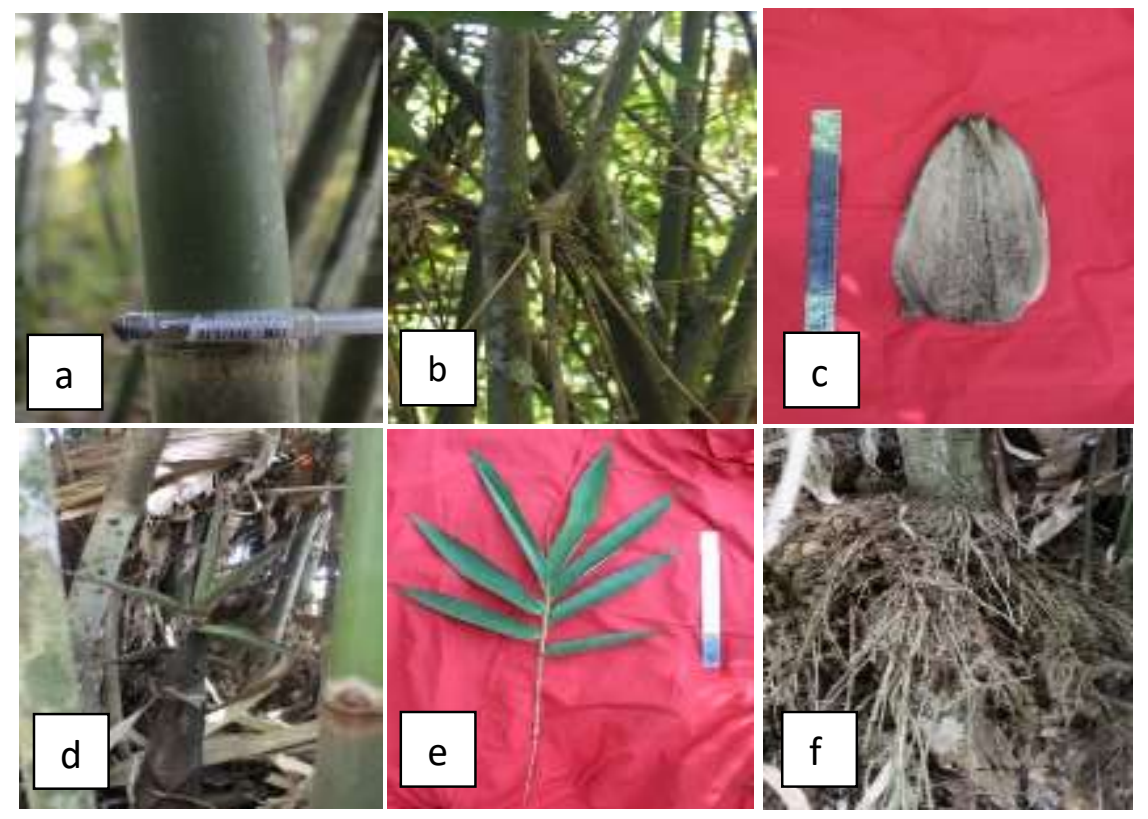

Gambar 1. Gigantochloa robusta (a)buluh (b)cabang (c)pelepah buluh (d) daun (e)rebung (f)Akar

\section{Bambu Tarek (Gigantochloa Balui)}

Batang bambu tarek memiliki rumpun yang sangat rapat, batang berwarna hijau tua bergaris kekuningan dengan ukuran dari yang kecil sampai ukuran sedang, bentuk batang lurus, permukaan batang licin dan mulus tidak ada bulu. Diameter batang antara $3-8 \mathrm{~cm}$, tinggi batang mencapai 7-30 meter, panjang ruas batang 27-45 $\mathrm{cm}$. Percabangan tumbuh tinggi diatas permukaan tanah dengan percabangan lateral dengan perkembangan yang baik. Daun pangkal daun berbentuk oval dengan ujung meruncing, warna daun berwarna hijau dengan permukaan daun agak halus dan balik daun banyak bulu halus, kuping pelepah daun seperti 
bingkai tingginya mencapai $1 \mathrm{~mm}$, ligula rata sampai menggerigi tingginya mencapai $2 \mathrm{~mm}$ dengan bulu kejur yang panjang mencapai $7 \mathrm{~mm}$, panjang daun 20-40 cm, lebar daun $2-5 \mathrm{~cm}$.

Pelepah berwarna coklat tertutup bulu berwarna putih dan mudah luruh, memiliki cuping dan ligula yang berkembang baik, daun pelepah batang menyandak atau terkeluk balik menyegitiga dengan pangkal sempit dan ujung meruncing, bagian punggung luar tertutup bulu putih, panjang daun pelepah buluh 5-8 $\mathrm{cm}$, panjang pelepah buluh 10-18 $\mathrm{cm}$ dan lebar $15-22 \mathrm{~cm}$. Rebung bambu tarek dengan bentuk mengkerucut, ditutupi pelepah berwarna hijau muda dan ditutupi bulu berwarna putih, diameter rebung tarek $2-7 \mathrm{~cm}$ warna puncuk rebung hijau dengan daun pelepah menyadak muda dengan ujung daun hijau keunguan. Akar bambu tarek berbentuk pakimorf (dicirikan oleh akar yang simpodial), akar terdapat dibawah tanah dan ada juga dibagian buku batang bagian bawah atau yang disebut akar udara, bagian pangkal akar lebih sempit dari pada ujungnya dan setiap ruas akar memiliki kuncup dan sedikit akar serabut yang tidak bercabang-cabang.

Habitat: bambu tarek tumbuh dengan baik pada tanah alluvial, sepanjang tepi sungai dan daerah tropis yang lembab, pada kawasan Hutan Tembawang Deret Jat Desa Peruan Dalam bambu tarek (Gigantochloa Balui) banyak tumbuh pada daerah tepian sungai.

Kegunaan: Bagian buluh digunakan masyarakat sebagai bahan baku bangunan (dinding rumah), keranjang sayur, jarei, dan tangkai untuk nangkap ikan.

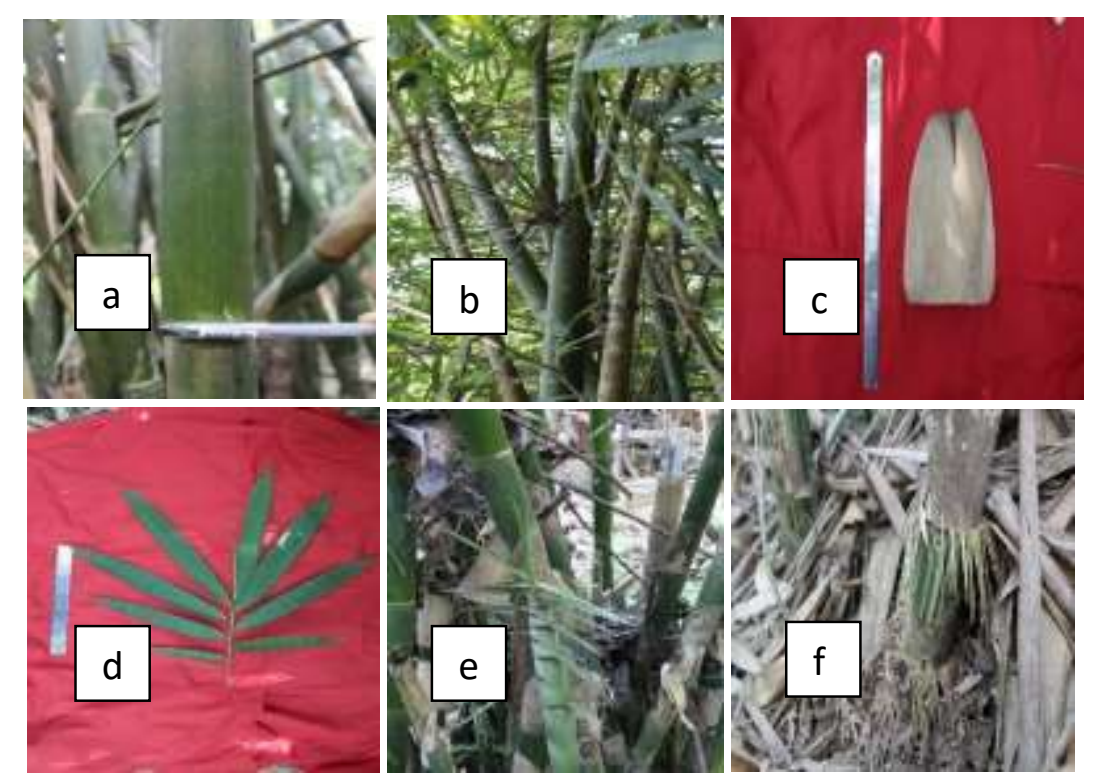

Gambar 2. Gigantochloa Balui (a) buluh (b) cabang (c) pelepah buluh (d) daun (e) rebung (f) akar 


\section{Bambu Borok (Schizostachyum zollingeri)}

Batang bambu borok memiliki rumpun yang rapat, lurus dan tegak, permukaan buluh agak halus dan licin berwarna hijau tua kekuningan, terdapat banyak bulu yang halus dibagian batang yang berwarna putih, panjang ruas 60-72 $\mathrm{cm}$, dimeter buluh3-10 $\mathrm{cm}$ dengan tinggi batang mencapai 15 meter, dinding buluh tipis $2-5 \mathrm{~mm}$. Percabangan tumbuh diatas 1,5 meter dari permukaan tanah dan besar cabang sama besar. Daun Permukaannya agak kasar dan balik daun memiliki bulu yang halus, warna daun hijau tua, bentuk pangkal daun oval dengan ujung daun meruncing, kuping pelepah daun pendek dengan bulu kejur yang panjangnya 1-2 $\mathrm{mm}$, panjang daun 20-40 cm, lebar daun 4$8 \mathrm{~cm}$.

Pelepah buluh tidak mudah luruh dan berwarna coklat muda tertutup bulu berwarna coklat, kuping pelepah buluh membulat dengan tinggi 3-5 mm, tutup buluh kejur panjang, ligula rata-rata tingginya $4 \mathrm{~mm}$, tutup bulu kejur pendek, memiliki cuping dan ligula yang
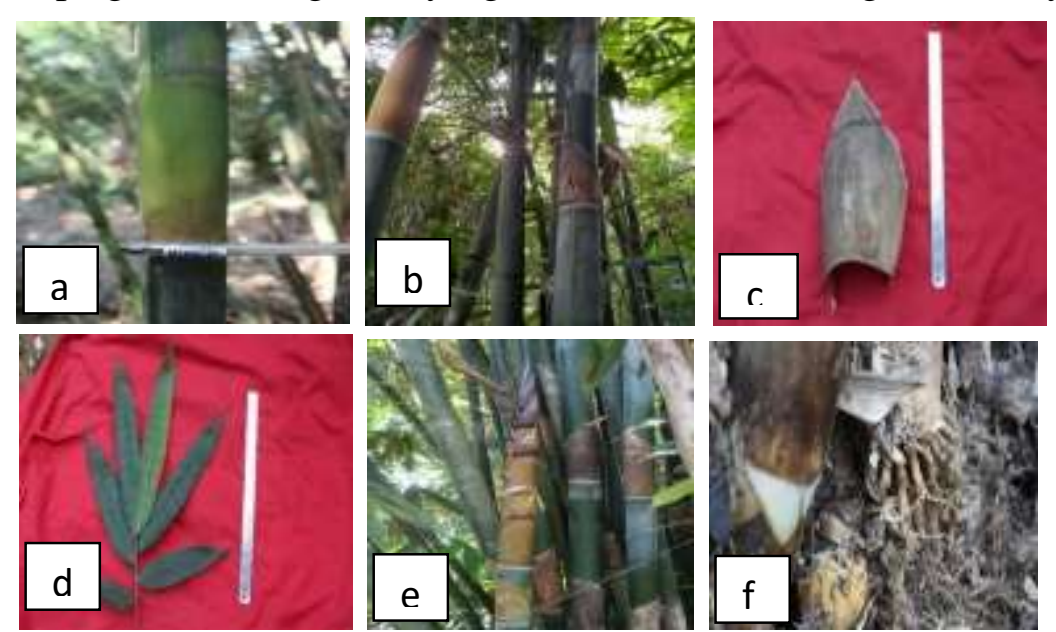

Gambar 3. Schizostachyum zollingeri (a) buluh (b) cabang (c) pelepah buluh (d) daun

(e) rebung (f) akar berkembang baik, daun pelepah batang tumbuh tegak dan berbentuk segitiga meruncing dengan panjang 3-5 cm, panjang pelepah 11-20 cm, dan lebar 14-34 $\mathrm{cm}$. Rebung berbentuk kerucut berwarna hijau ditutupi pelepah batang yang berwarna coklat kekuningan diselimuti bulu berwarna coklat dan ujung daun pelepah yang tegak bewarna kehitaman dan kekuningan, diameter rebung 3-10 cm. Akar bambu boro berbentuk pakimorf (dicirikan oleh akar yang simpodial), akar terdapat dibawah tanah, bagian pangkal akar lebih sempit dari pada ujungnya dan setiap ruas akar memiliki kuncup dan tumbuh akar serabut yang agak besar seperti akar jagung.

Habitat: Bambu borok tumbuh di daerah tropis yang lembab sampai kering di dataran rendah, di kawasan Hutan Tembawang Deret Jat Desa Peruan Dalam bambu borok banyak ditemukan pada kawasan yang kering.

Kegunaan: Buluh bambu borok digunakan masyarakat untuk masak lemang, masak sayur, masak daging dan dibuat bakul/ragak untuk nyuci sayur.
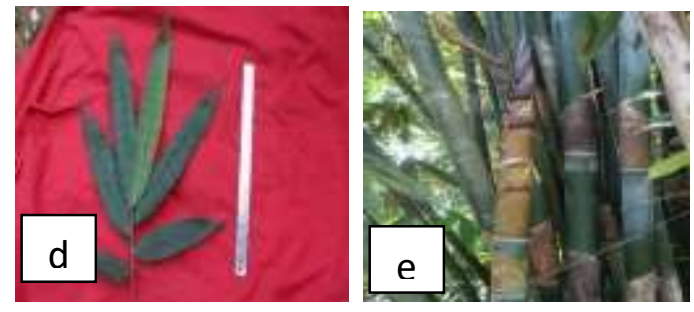


\section{Bambu Muntik (Schizostachyum sp)}

Batang bambu muntik memiliki rumpun yang agak rapat, bentuk buluh agak lurus, berwarna hijau tua kekuningan, bagian buluh banyak bulu yang kasar berwarna hitam kecoklatan dan permukaan buluh kasar, tinggi buluh 7-10 meter, panjang ruas buluh mencapai 25-30 cm, diameter buluh 2-5 cm, dengan tebal dinding tipi 1-3 mm, bukubuku tampak jelas menggelembung. Percabangan tumbuh jauh dari permukaan tanah dengan besar cabang sama. Daun berbentuk memanjang meruncing, pangkal daun oval, permukaan daun agak kasar, balik daun berbulu halus, warna daun hijau, kuping pelepah daun pendek dengan bulu kejur yang panjangnya 1-2 mm, ligula sangat pendek, panjang daun 18-28 cm dan lebar daun 3-5 cm.

Pelepah bambu muntik sangat lambat luruh dan berwarna coklat muda, hampir seluruh bagian pelepah di tutupi oleh bulu yang berwarna hitam coklat, pelepah bambu muntik tetap menempel atau tidak lepas dari buluh bambu sampai pelepahnya hancur sendiri, memiliki cuping dan ligula yang berkembang baik, daun pelepah batang menyandak atau terkeluk balik dengan ujung meruncing dengan panjang 6-9 cm, panjang pelepah 15-18 cm, dan lebar 10-16 cm. Rebung berbentuk kerucut berwarna hijau muda kekuningan ditutupi pelepah batang yang berwarna hijau kekuningan diselimuti bulu berwarna coklat dan ujung daun pelepah menyadak dan tegak bewarna hijau keunguan, diameter rebung 3-7 cm. Akar bambu muntik berbentuk pakimorf (dicirikan oleh akar yang simpodial), akar terdapat dibawah tanah, bagian pangkal akar lebih sempit dari pada ujungnya dan setiap ruas akar memiliki kuncup dan tumbuh akar serabut yang kecil bercabang-cabang.

Habitat: Bambu muntik tumbuh dilereng bukit, daerah lembab, pada kawasan Hutan Tembawang Deret jat Desa Peruan Dalam bambu muntik banyak ditemukan pada daerah lereng bukit.

Kegunaan: Bagian buluh bambu muntik digunakan masyarakat sebagai kandang ternak, sebagai tulang atap rumah daun dan bagian rebung digunakan sebagai sayuran. 


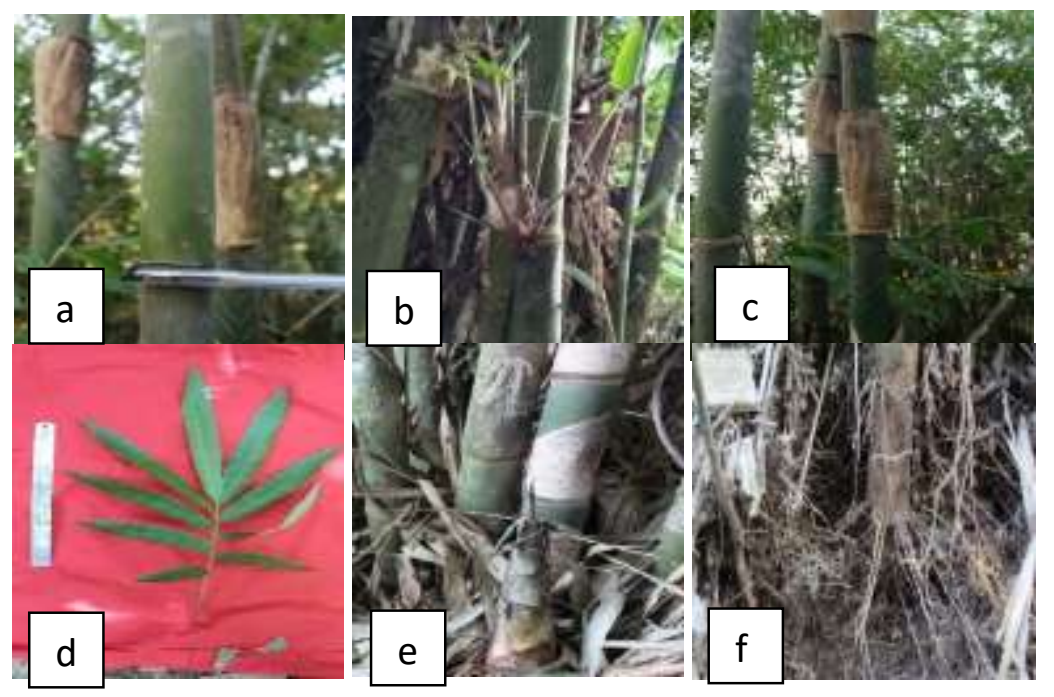

Gambar 4. Bambu Muntik (a) buluh (b) cabang (c) pelepah buluh (d) daun (e) rebung (f) akar

\section{Bambu Butuk (Dendrocalamus asper)}

Batang bambu butuk memiliki memiliki rumpun yang tidak terlalu rapat, bentuk batang tegak dengan ujung melengkung, warna buluh hijau, hijau keunguan,atau agak hijau keputih-putihan dan bertotol putih karena ada lumut ketika buluh tua, selain itu buku-bukunya dikelilingi akar udara dan permukaan buluh agak kasar dan terdapat bulu dan lumut yang menyelimuti buluh. Diameter batang antara 13-20 cm dan panjang antara ruas $35-50 \mathrm{~cm}$, tebal dinding buluh mencapai 5$10 \mathrm{~mm}$, tinggi batang mencapai 20-50 meter. Percabangan terdapat dibagian tengah buluh atau pada ketinggian 1,5-3 meter dari permukaan tanah, cabang terdiri dari 5-12 cabang dan memiliki satu cabang yang paling besar. Daun memiliki permukaan yang kasar, pangkal daun berbentuk oval dengan ujung meruncing, bawah daun agak berbulu halus, urat daun sejajar seperti rumput, memiliki tulang daun utama yang menonjol, bewarna hijau, panjang daun 19-35 cm, dan lebar daun 3-5 $\mathrm{cm}$, kuping pelepah daun kecil, tinggi 1-2 $\mathrm{mm}$, ligula rata dengan tinggi $2 \mathrm{~mm}$.

Pelepah buluh mudah luruh dan berwarna coklat, tertutup bulu hitam hingga coklat tua hingga membeledu, kupingnya menggulung dan kadang mengeriting, memiliki cuping dan ligula yang berkembang baik dan daun pelepah batang menyandak atau terkeluk balik dengan ujung meruncing, dengan panjang pelepah 50-61 cm, lebar 50-64 cm dan panjang daun pelepah $18-20 \mathrm{~cm}$. Rebung berbentuk kerucut berwarna putih kekuningan ditutupi pelepah batang yang berwarna coklat diselimuti bulu berwarna hitam dan ujung daun pelepah menyadak dan tegak bewarna coklat kehitaman, diameter rebung 7-25 cm. Akar bambu butuk berbentuk pakimorf (dicirikan oleh akar yang simpodial), akar terdapat dibawah tanah, tetapi ada juga yang berada dipermukaan tanah, dan terdapat akar yang tumbuh dibagian buku batang atau akar 
udara bagian pangkal akar lebih sempit dari pada ujungnya dan tumbuh akar serabut yang kecil yang banyak dan tebal sehingga memenuhi seluruh bagian pangkal akar.

Habitat: Bambu butuk tumbuh baik ditanah alluvial tropis yang lembab dan basah tetapi juga tumbuh di daerah kering didataran rendah maupun dataran tinggi, pada kawasan Hutan Tembawang Deret Jat Desa Peruan Dalam bambu butuk ditemukan tumbuh pada dataran rendah yang agak lembab. Kegunaan: Buluh bambu butuk digunakan masyrakat untuk mainan seperti meriam, peralatan rumah tangga dan bagian rebung digunakan untuk sayur.

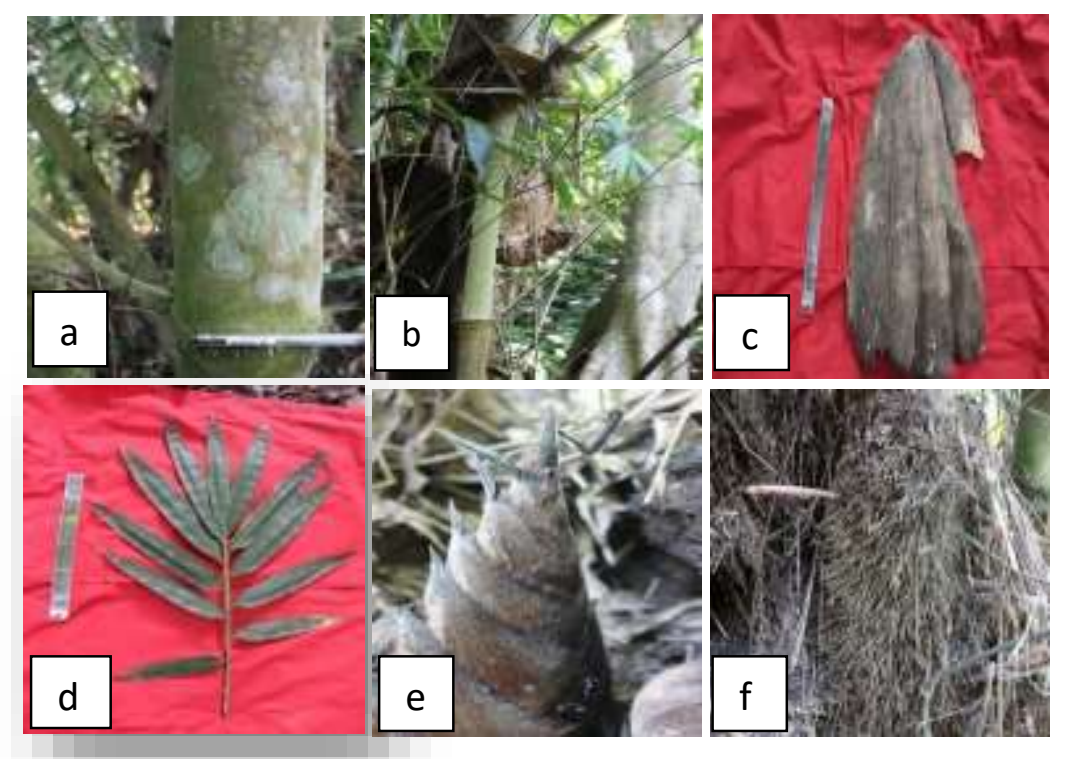

Gambar 5. Dendrocalamus asper (a) buluh (b) cabang (c) pelepah buluh (d) daun (e) rebung (f) akar

\section{Bambu Kuning (Schizostachyum brachycladum)}

Batang bambu kuning memiliki rumpun simpodial, tumbuh tegak dengan tinggi mencapai 20 meter dan tidak terlalu rapat, permukaan buluh agak halus berwarna kuning, terdapat banyak bulu yang halus dibagian batang yang berwarna putih, panjang ruas $20-25 \mathrm{~cm}$, dimeter buluh $5-10 \mathrm{~cm}$ dengan tinggi batang mencapai 15-20 meter, dinding buluh tebal 1-4 mm. Percabangan tumbuh diatas 1,5 meter dari permukaan tanah dengan cabang yang sama besar. Daun Permukaannya agak kasar dan balik daun memiliki bulu yang halus, warna daun hijau tua, bentuk pangkal daun oval dengan ujung daun meruncing, kuping pelepah daun pendek dengan bulu kejur yang panjangnya mencapai 1-2 $\mathrm{mm}$, panjang daun 9-25 $\mathrm{cm}$, lebar daun 3-7 cm.

Pelepah buluh mudah luruh dan berwarna coklat muda tertutup bulu berwarna hitam hingga coklat tua, kuping pelepah buluh membulat dengan ujung melengkung keluar tingginya $1-2 \mathrm{~cm}$, tutup buluh kejur panjang, ligula rata-rata tingginya 2-3 mm, tutup bulu kejur pendek, 
memiliki cuping dan ligula yang berkembang baik, daun pelepah batang tumbuh tegak dan berbentuk segitiga meruncing dengan panjang 3-5 cm, panjang pelepah 11-20 cm, dan lebar 14-34 $\mathrm{cm}$. Rebung berbentuk kerucut berwarna kuning keputihan ditutupi pelepah batang yang berwarna coklat kekuningan diselimuti bulu berwarna coklat dan ujung daun pelepah yang tegak bewarna hiaju kekuningan, diameter rebung 2-7 cm. Akar bambu kuning berbentuk pakimorf (dicirikan oleh akar yang simpodial), akar terdapat dibawah tanah, bagian pangkal akar lebih sempit dari pada ujungnya dan setiap ruas akar memiliki kuncup dan tumbuh akar serabut yang agak besar tidak bercabang seperti akar jagung.

Habitat: Bambu kuning tumbuh didaerah yang sangat kering atau lembab dan dapat tumbuh didaerah yang tergenang air, pada kawasan Hutan Tembawang Deret Jat Desa Peruan Dalam bambu kuning tumbuh di daerah yang agak kering dibagian atas bukit.

Kegunaan: Bagian bambu kuning belum ada digunakan masyarakat karena bambu kuning cukup langka bagi masyarakat bambu ini dianggap bambu yang sakral yang tidak bisa ditebang sembarangan.
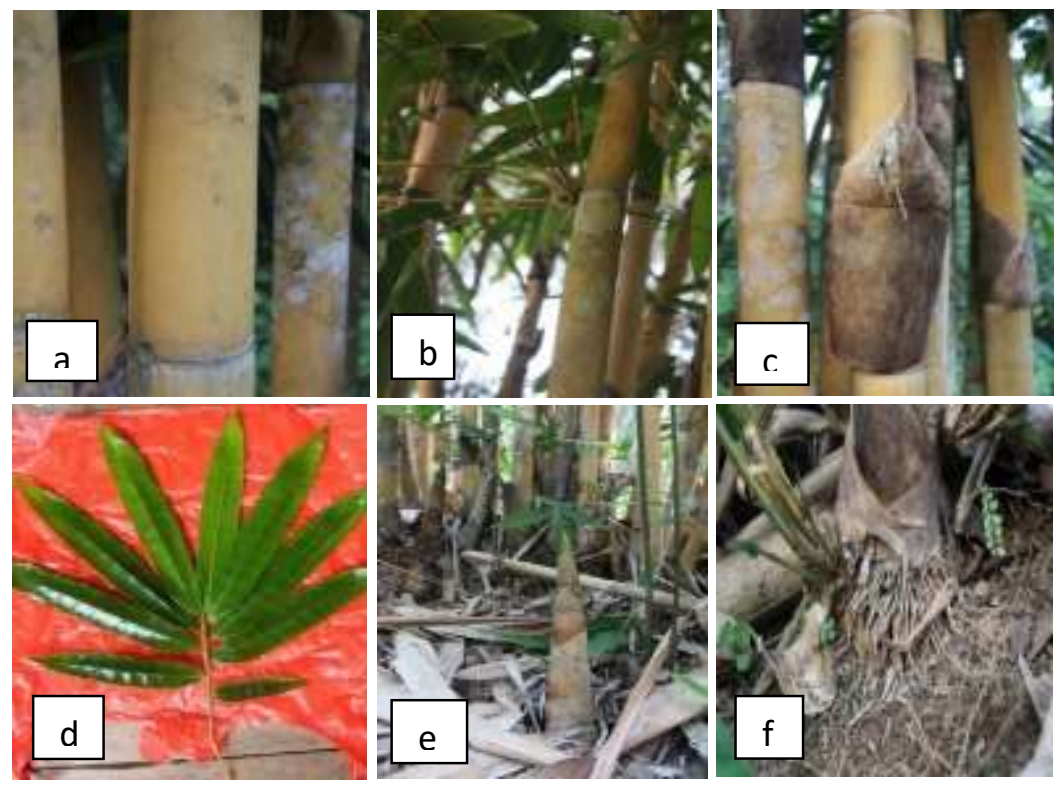

Gambar 6. Schizostachyum brachycladum (a) buluh (b) cabang (c) pelepah buluh (d) daun (e) rebung (f) akar

\section{Bambu Temiang Pogok (Schizostachyum silicatum)}

Batang bambu temiang pogok memiliki memiliki rumpun yang simpodial, tegak dan rapat dengan ujung agak melengkung, warna buluh muda hijau kekuningan dibawah buku terdapat bulu berwarna putih, ketika tua buluh berwarna hijau bertotol hitam dan banyak bulu halus. Diameter buluh antara 1-3 cm dan panjang antara ruas $65-76 \mathrm{~cm}$, tebal dinding buluh mencapai 1-2 $\mathrm{mm}$, tinggi batang mencapai 8-12 meter. Percabangan terletak jauh dari permukaan tanah, cabang sama besar. Daun 
memiliki permukaan yang kasar, pangkal daun berbentuk oval dengan ujung meruncing, permukaan bawah daun berbulu halus, urat daun sejajar seperti rumput, memiliki tulang daun utama yang menonjol, bewarna hijau, pelepah daun agak berbulu terutama bagian ujung dan tepi, kuping pelepah daun melengkung keluar dan mudah patah dengan 1-2 mm, panjang bulu kejur $3 \mathrm{~mm}$, tinggi ligula 1 $\mathrm{mm}$ rata dan gundul, panjang daun 15-28 $\mathrm{cm}$, dan lebar daun 3-5 cm.

Pelepah buluh tidak mudah luruh berwarna coklat, tertutup bulu hitam hingga coklat tua hingga membeledu, kuping pelepah tidak nampak, bulu kejur mudah patah dengan tinggi 1-6 mm, ligula menggerigi tingginya mencapai $1 \mathrm{~mm}$, cuping dan ligula yang berkembang baik dan daun pelepah buluh menyandak atau terkeluk balik dengan ujung meruncing, dengan panjang pelepah $22-25 \mathrm{~cm}$, lebar 12-14 cm dan panjang daun pelepah 9-15 $\mathrm{cm}$. Rebung berbentuk kerucut berwarna hijau muda ditutupi pelepah batang yang
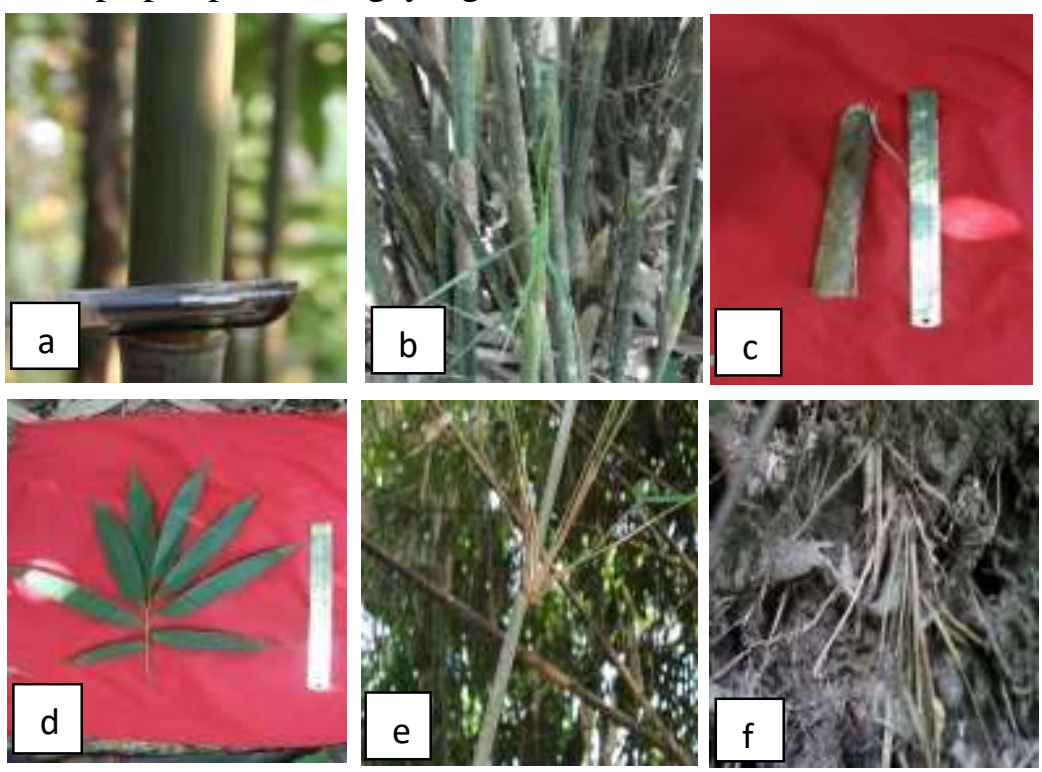

Gambar 7. Schizostachyum silicatum (a) buluh (b) cabang (c) pelepah buluh (d) daun (e) rebung (f) akar berwarna hijau diselimuti bulu berwarna coklat dan ujung daun pelepah yang menyadak dan tegak bewarna hiaju, diameter rebung 1-2 $\mathrm{cm}$. Akar bambu temiang pogok berbentuk pakimorf (dicirikan oleh akar yang simpodial), akar terdapat dibawah tanah, bagian pangkal akar lebih sempit dari pada ujungnya dan setiap ruas akar memiliki kuncup dan tumbuh akar serabut yang agak besar tidak bercabang.

Habitat: Bambu temiang pogok tumbuh ditepi hutan tropis yang lembab, tepi sungai dan dilereng bukit dataran rendah, pada kawasan Hutan Tembawang Deret Jat Desa Peruan Dalam bambu mayakng tumbuh di daerah antara tepian hutan tropis dengan tepian sungai.

Kegunaan: Bagian Buluh digunakan masyarakat untuk mainan anak-anak seperti sumpit, buat alat musik seperti suling, dan buluh muda digunakan untuk acara ritual adat untuk menyimpan tuak dan air.
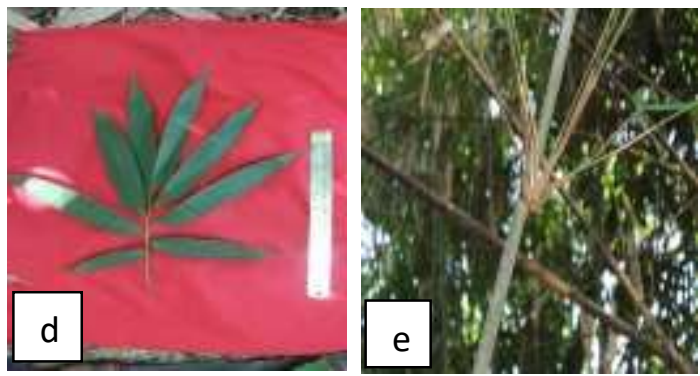
(e) rebung (f) akar 


\section{Kesimpulan}

Pada kawasan Hutan Tembawang Deret Jat desa Peruan Dalam Kecamatan Tayan Hulu ditemukan sebanyak 7 jenis. Adapun jenis bambu yang ditemukan pada kawasan ini, yaitu Bambu Ringko (Gigantochloa robusta), Bambu Tarek (Gigantochloa balui),Bambu Borok (Schizostachyum zollingeri), Bambu Muntik (Schizostachyum sp), Bambu Butuk (Dendrocalamus asper), Bambu Kuning (Schizostachyum brachycladum), dan Bambu Mayakng (Schizostachyum silicatum). Dari 7 jenis bambu, 3 jenis bambu yang rumpunnya paling banyak ditemukan yaitu Bambu Ringko (Gigantochloa robusta) sebanyak 76 rumpun, Bambu Tarek (Gigantochloa balui) sebanyak 84 rumpun dan Bambu Muntik (Schizostachyum sp) sebanyak 93 rumpun, dan hanya terdapat 3 genus bambu Dendrocalamus, Gigantochloa dan Schizostachyum, dan satu family Poaceae.

\section{DAFTAR PUSTAKA}

Agus, I . 2006. Identifikasi Potensi Kawasan Pengembangan Budidaya
Tanaman Bambu. Kabupaten Gunung Kidul Yogyakarta.

Dransfield, S. and E. A. Widjaja, 1995. Plant Resources of South-East Asia 7. Bamboos.Leiden: Backhuys Publisher.

Huzaemah, Mulyaningsih T, Aryanti E. 2016. Identifikasi Bambu pada Daerah Aliran Sungai Tiupupus Kabupaten Lombok Utara. Jurnal Biologi Tropis. 16(2):23-36.

Widjaja WA. 2001. Identifikasi Jenis-Jenis Bambu Di Jawa. Bogor: Pusat Penelitian Dan Pengembangan Biologi - LIPI.

Widjaja, E. A. Dan Karsono. 2004. Keanekaragaman bambu di Pulau Sumba. Jurnal Biodiversitas, 6 (2): 95-99.

Widjaja EA. 1997. Konservasi jenis-jenis bambu di Indonesia. Prosiding Seminar Nasional Konservasi Flora Nusantara. UPT Balai Pengembangan Kebun Raya BogorLIPI, Bogor. 